\title{
STOICHIOMETRY CONTROL OF COMPOUND SEMICONDUCTOR CRYSTALS
}

(Part three )

Jun-ichi Nishizawa ${ }^{1)}$, Yutaka Oyama ${ }^{2)}$

\begin{abstract}
Effects of stoichiometry on various feature of III-V compounds are investigated. The application of the optimum vapor pressure of group $\mathrm{V}$ elements is shown to minimize the deviation from the stoichiometric composition. Temperature dependence of the optimum vapor pressure is also obtained from both the annealing and the liquid phase epitaxial (LPE) growth experiments. Vapor pressure technology is successfully applied to the bulk crystal growth. In view of the defect formation mechanism, role of the stable interstitial As atoms $\left(\mathrm{I}_{\mathrm{As}}\right)$ in GaAs is emphasized. From the recent photocapacitance results, it is also shown that the excess group $\mathrm{V}$ atoms is also important for the formation of stoichiometry-dependent deep levels in InP and AlGaAs crystals. Even in the research field of surface science, it is shown that the precise control of stoichiometric composition should be required. Mechanism of the stoichiometry control is discussed on the basis of the equality of chemical potentials and the change of saturating solubility in the liquidus phase as a function of the vapor pressure. Stoichiometry-control should be also important in the field of the superconducting ceramics.
\end{abstract}

\section{GaAIAS VERY BRIGHT LED AND STOICHIOMETRY-DEPENDENT DEEP LEVELS}

The temperature difference method under controlled vapor pressure (TDM-CVP) has been also applied to the liquid phase epitaxial (LPE) of AlGaAs, InGaP and AlGaAsP ternary and quoternary compound semiconductor crystals. Super bright LED was already fabricated with the quantum efficiency up to $30 \%$. Temperature difference method is suitable for the mass-production because of its constancy of growth temperature.

Fig. 1 shows the As vapor pressure dependence of etch pit density (EPD) in $\mathrm{Al}_{\mathrm{x}} \mathrm{Ga}_{1-\mathrm{x}} \mathrm{As}(\mathrm{x}=0.3)$. EPD shows minimum value under a specific As vapor pressure. Optimum As vapor pressure should be dependent on the composition $\mathrm{x}$. Precise control of the deviation from the stoichiometric composition is expected to improve luminous efficiency.

Tohoku University, Katahira Aoba-ku 2-1-1, Sendai 980, Japan

2) Semiconductor Research Institute, Semiconductor Research Foundation,

Kawauchi Aoba-ku, Sendai 980, Japan 


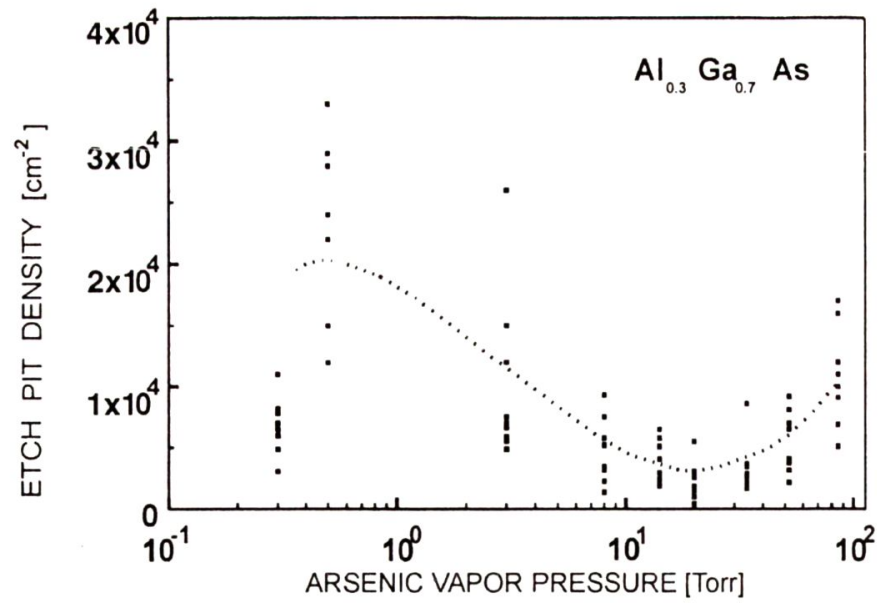

Fig. 1. As vapor pressure dependence of etch pit density EPD in LPE grown $\mathrm{Al}_{\mathrm{x}} \mathrm{Ga}_{1-\mathrm{x}} \mathrm{As}(\mathrm{x}=0.3)$. EPD shows minimum value under a specific As vapor pressure.

In AlGaAs ternary alloy systems, the so-called DX center has been greatly concerned with its effect on the electrical characteristics of the AlGaAs-base device like the high electron mobility transistor (HEMT) and so on. In view of the defect structure, many investigations have been also reported to explain its large difference between thermal and optical activation energy. Many models have been proposed for the atomic structure of the DX center [1]. In 1977, Nishizawa et al. reported that the photocapacitance (PHCAP) measurements revealed the major deep centres in AlGaAs at $\sim 0.65 \mathrm{eV}$ below the conduction band with its persistent photoconductivity (PPC) effects at low temperature. Later, this deep level is called as the DX center in AlGaAs [2].

It has been reported that the so-called DX center is formed in n-type AlGaAs with the $\mathrm{Al}$ composition $\mathrm{x} \pm 0.22$, and that the density of the DX center is nearly equal to the donor concentration. In conjunction with other results, it has been proposed that the origin of the DX center will be the donor impurity its self [3]. However, the effects of nonstoichiometry on the deep levels in AlGaAs has not been clarified yet.

In this section, the PHCAP and the deep level photoluminescence and Hall coefficient measurements are applied to the LPE-grown $n-\mathrm{Al}_{0.3} \mathrm{Ga}_{0.7} \mathrm{As}$ doped with $\mathrm{Te}$ followed by the annealing under controlled arsenic vapor pressure. Then, the effects of arsenic vapor pressure on the formation of the dominant deep levels are shown.

Te-doped $\mathrm{Al}_{x} \mathrm{Ga}_{1-x} \mathrm{As}(\mathrm{x}=0.33 \pm 0.02)$ layers were epitaxially grown by the LPE method of the temperature difference method under controlled arsenic vapor pressure (TDM-CVP). Substrates used were intentionally-undoped semi-insulating (SI) GaAs prepared by the pressure controlled Czochralski method. Crystallographic orientation of the substrates was $\{100\}$.

Both crystal growth and heat treatment were performed under controlled arsenic vapor pressure in Pd-purified $\mathrm{H}_{2}$ ambient. The growth temperature was kept constant at $650 \pm 5^{\circ} \mathrm{C}$ and the growth time was $60 \mathrm{~min}$. The arsenic vapor pressure applied during crystal growth was fixed to be 0.9 Torr in the present experiments. The 
average thickness of epitaxial layers obtained was $\sim 1 \mu \mathrm{m}$. After the epitaxial growth, the samples were heat-treated at $900 \pm 5^{\circ} \mathrm{C}$ for 1 hour under different arsenic vapor pressures in the LPE system. The AlGaAs crystal in a carbon crucible and the metal As were connected with a fine quartz tube. The arsenic vapor pressure $\mathrm{P}_{\mathrm{AIGaAs}}$ applied on $\mathrm{A}_{\mathrm{x}} \mathrm{Ga}_{1-\mathrm{x}}$ As sample at the temperature of $\mathrm{T}_{\mathrm{AlGaAs}}$ was determined as

$$
\mathrm{P}_{\text {AlGaAs }}=\mathrm{P}_{\mathrm{As}}\left(\mathrm{T}_{\mathrm{AlGaAs}} / \mathrm{T}_{\mathrm{As}}\right) 1 / 2
$$

Where $P_{A s}$ is the equilibrium arsenic vapor pressure determined by the temperature of metal As at $\mathrm{T}_{\mathrm{As}}(\mathrm{K}), \mathrm{T}_{\mathrm{AlGaAs}}(\mathrm{K})$ is the temperature of $\mathrm{A}_{\mathrm{x}} \mathrm{Ga}_{1-x} \mathrm{As}$ crystal. The equilibrium arsenic vapor pressure value used was obtained from the data by Honig [4]. After heat treatment, the samples were rapidly cooled to the nominal room temperature by removing the furnace from the place at the crystals. Aluminium composition of the epitaxial layers was determined by the PL method and the electron probe microanalysis (EPMA). Secondary ion mass spectroscopy (SIMS) analysis was applied to obtain depth profiles of $\mathrm{Al}$ composition and Te content in the epitaxial layers. After heat-treatments, no noticeable change in Al composition could be observed by PL and EPMA. SIMS measurements cannot reveal serious change in the depth profile of $\mathrm{Al}$ composition nor Te content.

The free-carrier concentration and the Hall mobility were obtained by the van der Pauw's method at room temperature. Indium dots with $5 \mathrm{wt} \%$ tin followed by alloying in pure $\mathrm{H}_{2}$ gas at $400^{\circ} \mathrm{C}$ for 5 minutes were used to obtain ohmic contacts.

The PL measurements were carried out at $77 \mathrm{~K}$ by immersing the samples in liquid $\mathrm{N}_{2}$. The excitation light used was an Ar-ion laser operating at $514.5 \mathrm{~nm}$ with an intensity of $150 \mathrm{~mW}$. The PL light was analyzed by the Spex grating monochromator with a cooled Ge photo-detector or a photomultiplier with S-1 type photoresponse, depending on the spectral region. The PL spectra shown here were calibrated by the spectral response of the measurement system.

PHCAP measurements were also carried out under constant voltage condition at $77 \mathrm{~K}$. For the PHCAP measurements, Si doped $n^{+}$- GaAs crystals $\left(\mathrm{n}=2 \times 10^{18} \mathrm{~cm}^{-3}\right)$ were used as the substrates for the crystal growth. In order to make metal/semiconductor diodes, Au was evaporated onto a sample surface after AuGe/Au on the back surface was alloyed at $450^{\circ} \mathrm{C}$ for 1 minute in pure $\mathrm{H}_{2}$ to provide an ohmic contact.

The sample diode was cooled in the dark by applying forward bias voltage from room temperature to $77 \mathrm{~K}$. Then, monochromatic light was irradiated from the long wavelength into a depletion region of the sample diode. Ionized level density was determined as

$$
\Delta \mathrm{Nt}=\left(\mathrm{V}_{\mathrm{dep}}-\mathrm{V}_{\mathrm{appl}}\right) \times(2 / \varepsilon \mathrm{q}) \times\left(\mathrm{C}_{\mathrm{ph} 2}-\mathrm{C}_{\text {dark2}}\right)
$$

where $\Delta \mathrm{Nt}$ is the ionized level density, $\mathrm{V}_{\text {dep }}$ is the diffusion potential, $\mathrm{V}_{\text {appl }}$, is the applied voltage, $\varepsilon$ is the dielectric constant.

Fig. 2 shows the PHCAP spectra of the Te-doped $n-\mathrm{Al}_{0.3} \mathrm{Ga}_{0.7} \mathrm{As}$ grown from the AlGaAs solution with the $0.01 w t \%$ Te content. After crystal growth, each samples were 


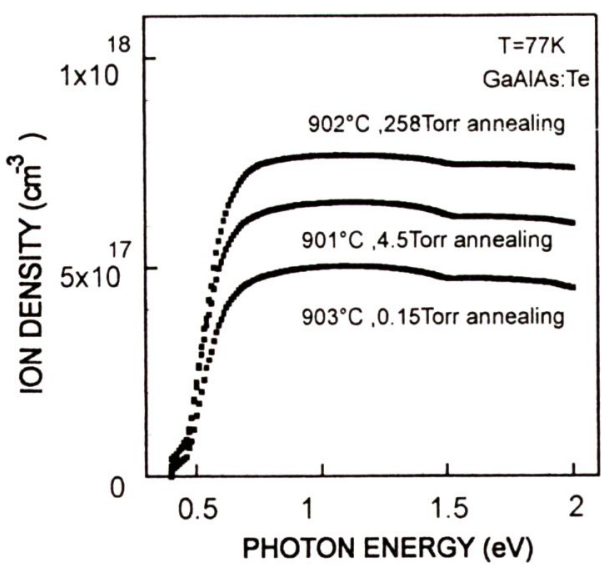

Fig. 2. Ion density PHCAP spectra of the Tedoped $n-\mathrm{Al}_{0.3} \mathrm{Ga}_{0.7}$ As grown from the AlGaAs solution with the $0.01 \mathrm{wt} \% \mathrm{Te}$ content.

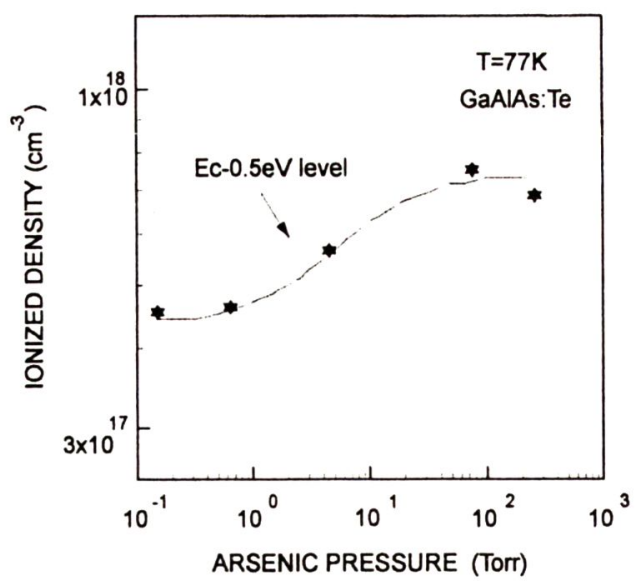

Fig. 3. Change of $E_{C}-0.5 e V$ level density as a function of arsenic vapor pressure during annealing.

annealed under different arsenic vapor pressure. In Fig. 2, the increase of ion density is caused by the photoionization of the occupied deep donors and the decrease of ion density is caused by the neutralization of the ionized levels. It is shown that the dominant deep level in $n$-AlGaAs doped with Te locates at $0.5 \mathrm{eV}$ below the conduction band.

Fig. 3 shows the change of $\mathrm{E}_{\mathrm{c}}-0.5 \mathrm{eV}$ level density as a function of arsenic vapor pressure during annealing. It is shown that the ionized level density of $\mathrm{E}_{\mathrm{c}}-0.5 \mathrm{eV}$ level

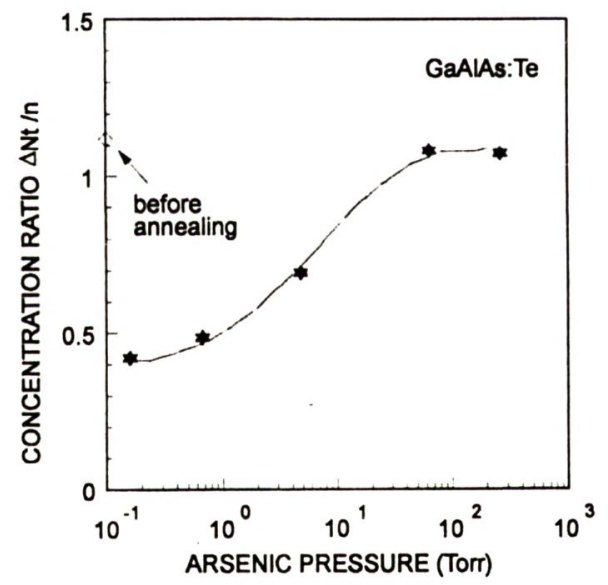

Fig. 4. Ratio of carrier concentration $n$ at $300 \mathrm{~K}$ and $\mathrm{E}_{\mathrm{C}}-0.5 \mathrm{eV}$ level density $\triangle \mathrm{Nt}$ by PHCAP measurement at $77 \mathrm{~K}$. The epitaxial layers were Te-doped $n$ - $\mathrm{Al}_{0.3} \mathrm{Ga}_{0.7} \mathrm{As}$ grown from the $\mathrm{AlGa}$ As solution with the $0.01 \mathrm{wt} \% \mathrm{Te}$.

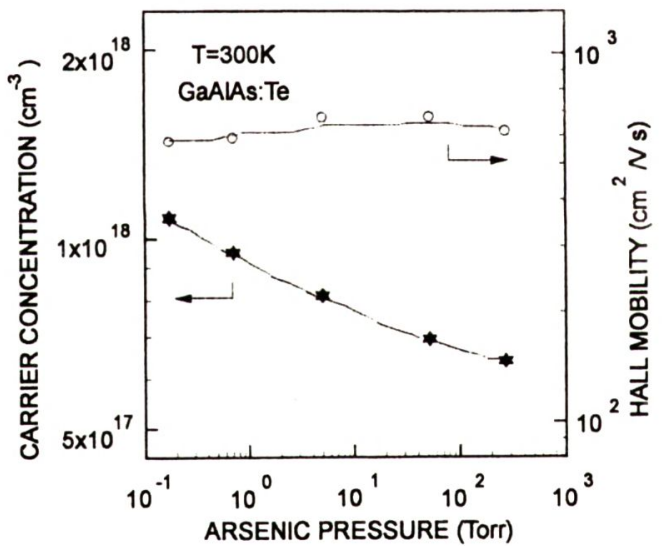

Fig. 5. Effect of arsenic vapor pressure during the annealing on the carrier concentration and Hall mobility. The samples were Te-doped $n$ $\mathrm{Al}_{0.3} \mathrm{Ga}_{0.7} \mathrm{As}$ grown from the AlGaAs solution with the $0.01 \mathrm{wt} \% \mathrm{Te}$. 
increases with increase of the applied arsenic vapor pressure.

Fig. 4 shows the ratio of carrier concentration $n$ at $300 \mathrm{~K}$ and $\mathrm{E}_{\mathrm{c}}-0.5 \mathrm{eV}$ level density $\triangle \mathrm{Nt}$ by PHCAP measurement at $77 \mathrm{~K}$. The epitaxial layers were Te-doped $n$ $\mathrm{Al}_{0.3} \mathrm{Ga}_{0.7} \mathrm{As}$ grown from the $\mathrm{AlGaAs}$ solution with the $0.01 \mathrm{wt} \% \mathrm{Te}$. It is noticed that the concentration ratio $\Delta \mathrm{Nt} / \mathrm{n}$ becomes larger as arsenic vapor pressure during annealing increases and then saturates. Therefore, it is shown that the dominant deep level density at $\mathrm{E}_{\mathrm{c}}-0.5 \mathrm{eV}$ is determined not only by the shallow donor concentration but also by the excess arsenic composition of AlGaAs crystals.

Fig. 5 shows the effect of arsenic vapor pressure during the annealing on the carrier concentration and Hall mobility. The samples were Te-doped $n-\mathrm{Al}_{0.3} \mathrm{Ga}_{0.7} \mathrm{As}$ grown from the AlGaAs solution with the $0.01 \mathrm{wt} \% \mathrm{Te}$. It is shown that the carrier concentration decreases as arsenic vapor pressure increases, and the Hall mobility is almost constant. This indicates that the compensating deep levels can be induced by the annealing under high arsenic vapor pressure. This can be also confirmed from the PHCAP results.

Fig. 6 shows the relation between the Te content in AlGaAs solution at the crystal growth and the carrier concentration as a function of arsenic vapor pressure during annealing. The carrier concentration in the as-grown epitaxial layers increases with increase of Te content and then saturates to $1.2 \times 10^{18} \mathrm{~cm}^{-3}$. It is shown that the carrier concentration of the epitaxial layer annealed under lower arsenic pressure (0.2 Torr) increases compared with that annealed under higher arsenic vapor pressure (310 Torr).

Fig. 7 shows the carrier concentration dependencies of the Hall mobility as a function of the arsenic vapor pressure applied during the annealing. It is shown that the annealing under higher arsenic vapor pressure reduces the Hall mobility in an

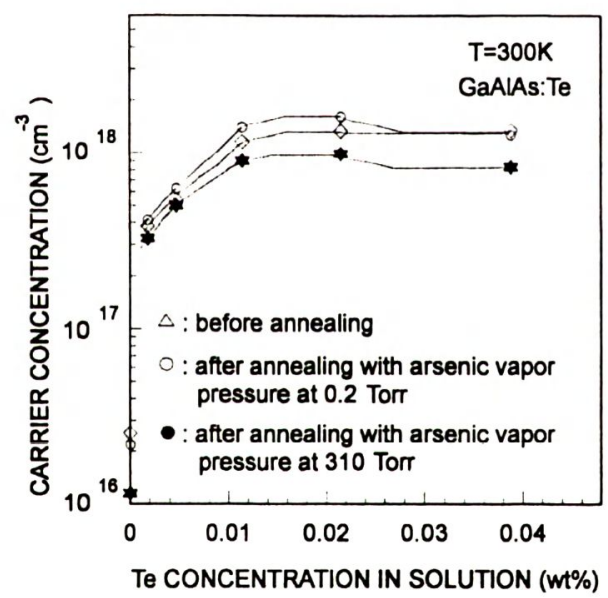

Fig. 6. Relation between the Te content in $\mathrm{AlGaAs}$ solution at the crystal growth and the carrier concentration as a function of arsenic vapor pressure during annealing.

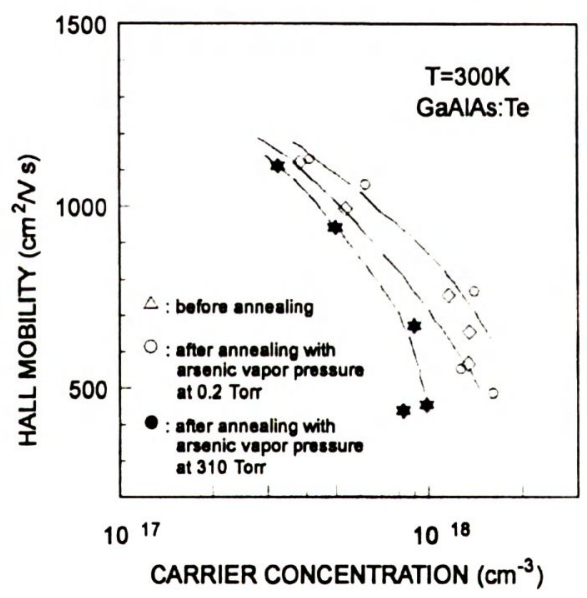

Fig. 7. Carrier concentration dependencies of the Hall mobility as a function of the arsenic vapor pressure applied during the annealing. 
epitaxial layer with an identical carrier concentration. In addition, the annealing under lower arsenic vapor pressure improves the crystal quality in view of the Hall mobility. As mentioned previously, the PL band-edge emission and the EPMA measurements cannot reveal serious change in $\mathrm{Al}$ composition by the 1 hour-annealing at $900^{\circ} \mathrm{C}$. The secondary ion mass spectroscopy (SIMS) measurements also show the flat depth profile of $\mathrm{Al}$ and $\mathrm{Te}$ content even after annealing regardless of the change of applying arsenic vapor pressure. Therefore, the annealing effects on the change of $\mathrm{Al}$ composition and redistribution of $\mathrm{Te}$ can be safely ignored. Then, it is considered that the

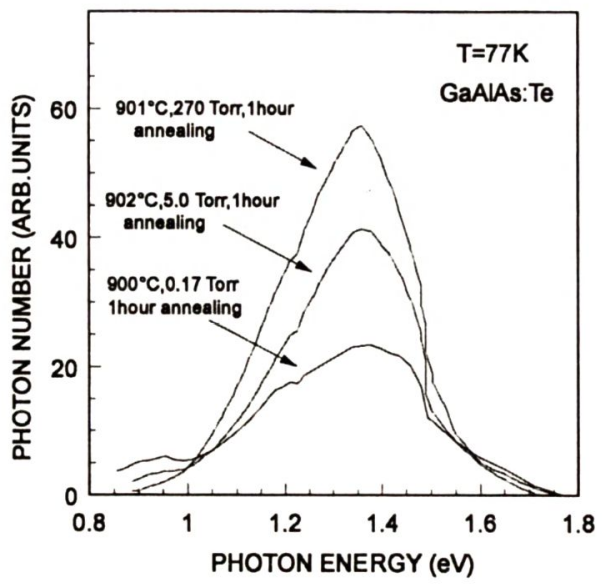

Fig. 8. Typical deep level PL spectra of LPE AlGaAs at $77 \mathrm{~K}$.

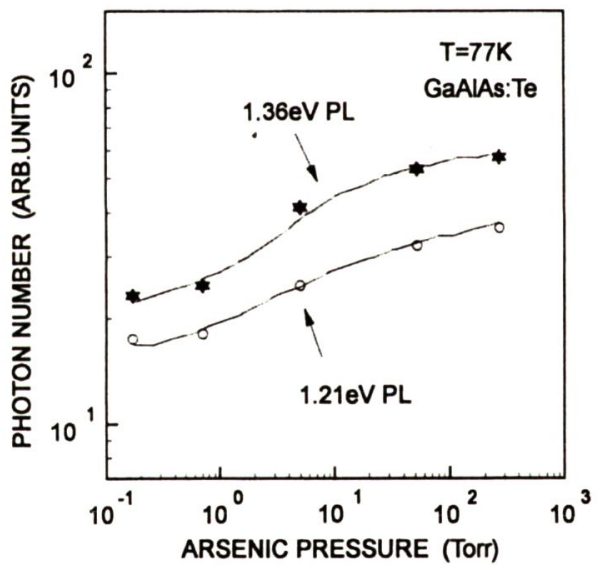

Fig. 9. Arsenic vapor pressure dependency of the 1.21 and $1.36 \mathrm{eV}$ PL band intensity. The starting epitaxial layers were grown from the AlGaAs solution with the Te content of $0.01 \mathrm{wt} \%$. annealing under excess arsenic vapor pressure introduces the stoichiometry-dependent defects in AlGaAs crystal.

Typical deep level PL spectra at $77 \mathrm{~K}$ are shown in Fig. 8. Two kinds of dominant PL bands were detected at 1.21 and $1.36 \mathrm{eV}$ commonly in both the as-grown and the annealed $n$-AlGaAs ( $\mathrm{x}=0.3)$ :Te epitaxial layers. These PL bands were also observed in $\mathrm{Te}$ doped $n-\mathrm{Al}_{\mathrm{x}} \mathrm{Ga}_{1-\mathrm{x}} \mathrm{As}$ $(x=0.46)$ after annealing at $900{ }^{\circ} \mathrm{C}$ for 67 hour. However, these PL bands cannot be detected in both intentionally-undoped $n$ type and $\mathrm{Mg}$ doped $p$-type $\mathrm{Al}_{\mathrm{x}} \mathrm{Ga}_{1-\mathrm{x}} \mathrm{As}$ $(0<x<0.8)$ epitaxial layers. In addition, whereas such PL band cannot be detected in the SI GaAs substrate used, the 1.21 and $1.36 \mathrm{eV}$ PL band intensity increases with the thickness up to $\sim 1 \mu \mathrm{m}$ and reaches to the constant value. SIMS depth profiling also shows flat $\mathrm{Al}$ composition and Te content in the epitaxial layers even after 1 hour-annealing at $900^{\circ} \mathrm{C}$. Therefore, it is considered that these deep level PL emissions are associated at least with impurity $\mathrm{Te}$ in $n$-AlGaAs and induced mainly in the epitaxial layer. As shown in Fig.8, the post-annealing under high arsenic vapor pressure enhances the 1.21 and $1.36 \mathrm{eV}$ PL band intensity.

Fig. 9 shows the arsenic vapor pressure dependency of the 1.21 and $1.36 \mathrm{eV}$ PL band intensity. The starting epitaxial layers were grown from the AlGaAs so- 
lution with the Te content of $0.01 \mathrm{wt} \%$. It is shown that the 1.21 and $1.36 \mathrm{eV}$ PL band intensity increases with increasing applied arsenic vapor pressure, and then saturates under high arsenic vapor pressure. This tendency looks to be similar with the arsenic vapor pressure dependency of the $\mathrm{E}_{\mathrm{C}}-0.5 \mathrm{eV}$ level density as shown in Fig.3. Fig. 10 and 11 show the Te content dependencies of the 1.21 and $1.36 \mathrm{eV}$ intensities in $\mathrm{Al}_{0.3} \mathrm{Ga}_{0.7} \mathrm{As}$ crystals as a function of arsenic vapor pressure. These two PL band intensities increase with increasing Te content and saturate when the Te content exceeds above $0.01 \mathrm{wt} \%$ in the solution. In addition, these deep level PL band intensities are enhanced by the annealing under high arsenic vapor pressure. From these results, it is shown that the deep level PL bands at 1.21 and $1.36 \mathrm{eV}$ are associated with at least both the donor impurity $\mathrm{Te}$ and the excess arsenic atoms in AlGaAs. And it is considered that these two PL bands are related with $\mathrm{Ec}-0.5 \mathrm{eV}$ level revealed by PHCAP measurement.

Many reports have been already published on the deep level PL bands in donordoped AlGaAs crystals. It has been reported that the $0.93 \mu \mathrm{m}(1.3 \mathrm{eV})-\mathrm{PL}$ band is observed at $77 \mathrm{~K}$ in Si-doped $\mathrm{Al}_{x} \mathrm{Ga}_{1-\mathrm{x}} \mathrm{As}(\mathrm{x}=0.3)$ grown by metallorganic chemical vapor deposition (MOCVD) method [5]. They pointed out the existence of the specific impurity content, above which the carrier concentration saturates while the PL band intensity increases further. However, different results were obtained in our present experimental conditions. Also they detected $0.93 \mu \mathrm{m}$-PL band only in the heavily doped samples $\left(\sim 5 \times 10^{17} \mathrm{~cm}^{-3}\right)$. They proposed that the origin of the PL band is concerned with donor-Ga vacancy complex. But other researchers [6] measured similar PL band at $4.2 \mathrm{~K}$ in Si-doped $\mathrm{A} 1_{x} \mathrm{Ga}_{1-\mathrm{x}}$ As $(\mathrm{x}=0.4)$ grown by MOCVD method. In those experiments, similar PL band can be detected in the samples even with the carrier concentration of $2 \times 10^{16} \mathrm{~cm}^{-3}$ at room temperature.

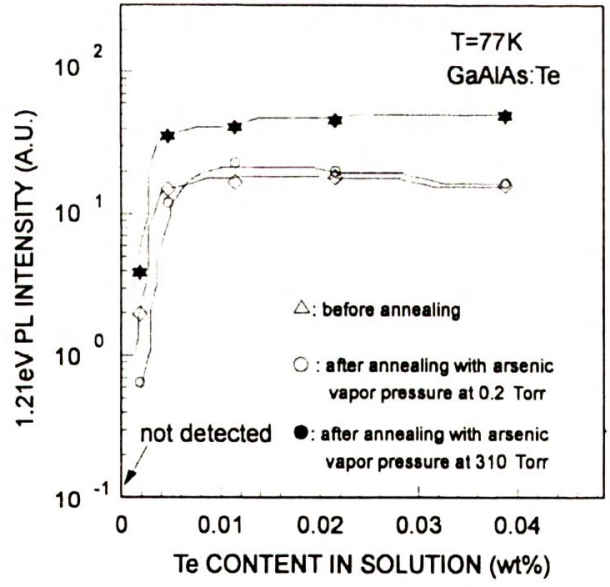

Fig. 10. Te content dependencies of the 1.21$\mathrm{PL}$ band intensities in $\mathrm{Al}_{0.3} \mathrm{Ga}_{0.7}$ As crystals as a function of arsenic vapor pressure.

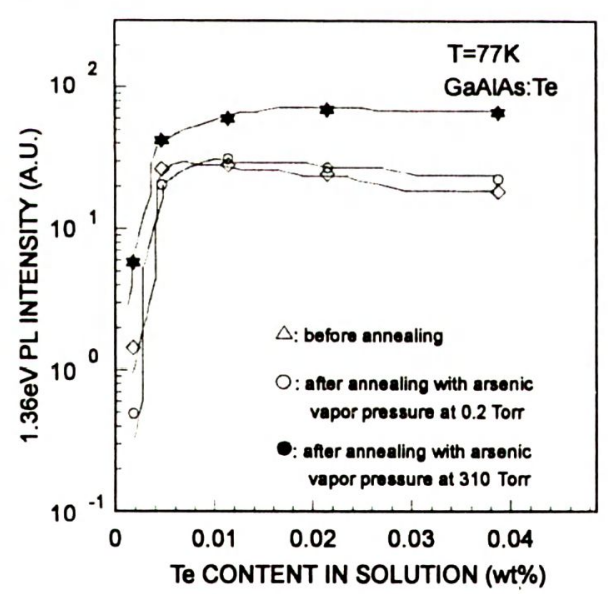

Fig. 11. Te content dependencies of the $1.36 \mathrm{eV}-\mathrm{PL}$ band intensities in $\mathrm{Al}_{0.3} \mathrm{Ga}_{0.7} \mathrm{As}$ crystals as a function of arsenic vapor pressure. 
In view of the $1.2 \mathrm{eV}$ PL band, it has been reported that the $1.2 \mathrm{eV}-\mathrm{PL}$ emission in Se-doped $\mathrm{Al}_{\mathrm{x}} \mathrm{Ga}_{1-\mathrm{x}} \mathrm{As}(\mathrm{x}=0.4)$ is associated with $\mathrm{DX}$ center and he suggested that it is consistently explained in terms of the large lattice relaxation model [7]. However, the particle induced X-ray emission (PIXE) measurements cannot reveal large lattice relaxation [8]. In view of the stoichiometry of AlGaAs crystals, Nishizawa et al. have detected the $\mathrm{E}_{\mathrm{v}}+0.47 \mathrm{eV}$ level by the PHCAP method in an intentionally undoped $n$-type $\mathrm{Al}_{\mathrm{x}} \mathrm{Ga}_{1-\mathrm{x}} \mathrm{As}(\mathrm{x}=0.1)$ grown by $\mathrm{LPE}$ under controlled arsenic vapor pressure. From the results of the arsenic vapor pressure dependence on the level density, it is proposed that the $\mathrm{E}_{\mathrm{v}}+0.47 \mathrm{eV}$ level is associated with arsenic interstitial atoms [9]. They also suggested that the optimum arsenic vapor pressure for $\mathrm{Al}_{\mathrm{x}} \mathrm{Ga}_{1}$. ${ }_{x}$ As is considerably lower than that for GaAs. The optimum arsenic vapor pressure for GaAs obtained was about 80 Torr at $900^{\circ} \mathrm{C}$. Therefore, it is considered that the excess arsenic atoms can be introduced by the present annealing condition under higher arsenic vapor pressure of 310 Torr.

From our present results, it is considered that the dominant deep levels in $n$ $\mathrm{Al}_{\mathrm{x}} \mathrm{Ga}_{1-\mathrm{x}} \mathrm{As}(\mathrm{x}=0.33)$ i.e. DX center are seriously affected by the deviation from the stoichiometric composition of the crystals and that these deep levels are at least associated with the donor impurity $\mathrm{Te}$ and the excess arsenic composition in the epitaxial layers.

\section{THEORETICAL CONSIDERATION OF STOICHIOMETRY CONTROL THROUGH SOLUTION}

The model for the mechanism of the vapor pressure control is described [10] under the concept that the chemical potentials of As in the three phase (gas, liquid and solid) are equal to each other under the applied vapor pressure. It is important that the temperature dependencies of the optimum vapor pressure is the same as that of the heat treatment experiments in which the solid phase is directly controlled by the applied vapor pressure by the equality of the chemical potentials of the solid and gas phases. The temperature difference between the molten phase and the substrate accelerates diffusion of dissolved GaAs towards the substrate and its segregation. The growth rate is controlled by the temperature difference but not by the applied vapor pressure if the source crystal is present on the top of the molten phase. Without temperature difference, it was confirmed that the As content in the liquid reaches a balanced value depending on the applied vapor pressure after application of the vapor pressure. This means that some kind of three-phase equilibrium is established for an arbitrary value of applied vapor pressure. The fundamental idea that the chemical potentials of As in the gas, liquid and solid phases becomes equal was first presented by Nishizawa in the literature. From our experimental result that the dominant nonstoichiometric defects in GaAs are As interstitial atoms at high As vapor pressure, it is assumed that these two kinds of point defects dominantly 
determine the chemical potentials of As as well as gallium in the solid phase. The presence of gallium vacancies and gallium interstitials are also taken into consideration, but they are assumed to be of smaller concentrations. On the other hand, the As chemical potential in the liquid phase was assumed to be determined by the GaAs molecules and some kind of As molecules or atoms in the liquid which are equilibrated to each other, in order to explain the very small but finite increase of solubility under an applied vapor pressure. It is shown that the optimum vapor pressure thus calculated was in good agreement with the experimentally obtained optimum vapor pressure, as a function of temperature.

\section{SUMMARY}

Te-doped $\mathrm{Al}_{x} \mathrm{Ga}_{1-x} \mathrm{As}(\mathrm{x}=0.33)$ crystals grown by LPE method, were annealed at $900^{\circ} \mathrm{C}$ for 1 hour under controlled arsenic vapor pressure. The PHCAP measurements revealed the dominant deep level located at $\mathrm{E}_{\mathrm{C}}-0.5 \mathrm{eV}$. The $\mathrm{E}_{\mathrm{C}}-0.5 \mathrm{eV}$ level density increased by the annealing under higher arsenic vapor pressure. The results of the Hall effect measurements also indicated the introduction of stoichiometry-dependent defects by annealing under higher arsenic vapor pressure. The deep level PL measurements detected the 1.21 and $1.36 \mathrm{eV}$ emissions at $77 \mathrm{~K}$ and the PL intensities were enhanced by the annealing under higher arsenic vapor pressure. From these results, it is considered that in AlGaAs:Te ternary alloy systems, the dominant deep levels i.e. DX center were seriously affected by the stoichiometric composition of the crystals, and that these deep levels are associated at least with the donor impurity $\mathrm{Te}$ and the excess arsenic composition.

Evaluation and control of the deviation from stoichiometry has been increasingly important in the field of compound semiconductor crystals. Each device process including crystal growth and diffusion etc. cannot be completed without consideration of the stoichiometry, because the compound semiconductor device requires precise control of electrical and optical characteristics. Then more precise control of stoichiometric composition should be required even in the field of surface science. Stoichiometry-control should be also important in the field of the superconducting ceramics.

\section{EDITORIAL NOTE}

The paper submitted by the authors was divided by the editor into three parts which were successively published. Part one, published "Materiały Elektroniczne" nr 4-1996 was dealing with deep levels related to GaAs stoichiometry. In part two, published in "Materiały Elektroniczne" nr 1-1997 deep level defects induced by the phosphorus pressure changes during growth and annealing of InP and $\mathrm{GaP}$ are discussed. Part three, which is published in this issue of "Materiały Elektroniczne" is dedicated to stoichiometry related defects in AlGaAs. 


\section{REFERENCES}

[1] Lang D.V., Rogan R.A., Jaros M.: Phys.Rev. B19, 19791015

Chadi D.J., Chang K.J.: Phys.Rev. B 39,14, 1989, 10063

Mooney P.M.: J.App1.Phys. 67, 3, 1990, R1

Dmochowski J.E., Dobaczewski L., Langer J.M.: Wolfgang Jantsch Phys.Rev.B 40,14, 1989, 9671

Cheong B.H., Chang K.J.: Phys.Rev.B 46, 20, 1992, 13131

[2] Nishizawa J., Suto K., Teshima T.: J.Appl.Phys. 48, 1977, 3484

[3] MizutaM., Tachikawa M.,Kukimoto H.: Jpn.J.Appl.Phys. 24, 2, 1985, L143

[4] Honig R.E.: RCA Rev. 30, 1969, 285

[5] Parsey M., Jr., Nanishi Y., Lagowski J. Gatos H.C.: J. Electrochem, Soc. 128, 1981, 937

[6] Visser E.P., Tang X., Wieleman R.W., Giling J.L.: J.App1.Phys. 69, 1991, 3266

[7] Kajikawa Y.: J. Appl.Phys. 69, 1991, 1429

[8] Yu K.M., Khachaturyan K., Weber E.R., Lee H.P., Colas E.G.: private communication

[9] Nishizawa J., Motozawa M., Oyama Y, Dezaki K., Fujishiro H., Suto K.: Jpn.J.Appl.Phys. $33,1994,1753$

[10] Nishizawa J., Okuno Y., Suto K.: Japan Annual Reviews in Electronics, Computers \& Telecommunications (JARECT), vol.19, Semiconductor Technologies ( 1986), ed. by J.Nishizawa, OHMSHA, LTD and North-Holland

\section{KONTROLA STECHIOMETRII KRYSZTAŁÓW ZWIĄZKÓW PÓŁPRZEWODNIKOWYCH}

W pracy przedstawiono wyniki badań wpływu stechiometrii na właściwości związków półprzewodnikowych typu $\mathrm{A}^{\mathrm{II}} \mathrm{B}^{\mathrm{V}}$. Pokazano, że optymalizacja ciśnienia par pierwiastków z V grupy układu okresowego, pozwala na zminimalizowanie odchyleń składu kryształów od składu stechiometrycznego. Optymalne ciśnienie par tych pierwiastków w funkcji temperatury wyznaczono dla procesów wygrzewania kryształów oraz ich wzrostu metodą epitaksji z fazy ciekłej. Stwierdzono także, że wyniki przeprowadzonej optymalizacji są przydatne do właściwego doboru warunków technologicznych podczas otrzymywania kryształów metodą krystalizacji kierunkowej. Przedstawiono mechanizmy generacji defektów punktowych uwzględniające wpływ ciśnienia par składników z V grupy. W szczególności podkreślono dużą rolę stabilnych atomów As w położeniach międzywęzłowych $\left(\mathrm{I}_{\mathrm{As}}\right)$ w powstawaniu defektów punktowych w GaAs. Na podstawie wyników badań metodą fotopojemnościową ustalono, że nadmiarowe atomy pierwiastków z V grupy biorą udział $\mathrm{w}$ procesie generacji głębokich centrów defektowych $\mathrm{w}$ InP i AlGaAs, których koncentracja zależna jest od stechiometrii kryształów. Wskazano również na wpływ stechiometrii na właściwości powierzchni kryształów. Przedstawiony sposób kontroli stechiometrii opracowany został dla kryształów związków półprzewodnikowych przy założeniu równości potencjałów chemicznych i przyjęciu, że rozpuszczalność graniczna składnika $\mathrm{V}$ grupy w fazie ciekłej jest funkcją ciśnienia jego par. Sposób ten może znaleźć zastosowanie także do kontroli stechiometrii nadprzewodzących materiałów ceramicznych. 